\title{
Effect of Stratification Period and Temperature on Germination Behaviour of Rhododendron arboreum Smith
}

\author{
Vipasha*, Sanyam, Navjot Singh Kaler and Varun Attri
}

Department of Silviculture and Agroforestry, University of Horticulture and Forestry, Nauni - 173 230, Solan, H.P., India

*Corresponding author

\section{A B S T R A C T}

The present work was conducted to study the effect of stratification period and temperature on germination behaviour of Rhododendron arboreum Smith under laboratory condition as

\begin{tabular}{|c|c|}
\hline Keywords & to its overexploitation of flowers and poor natural regeneration. The study involved \\
\hline $\begin{array}{l}\text { Rhododendron } \\
\text { arboreum, } \\
\text { Stratification } \\
\text { period, } \\
\text { Temperature, } \\
\text { germinability }\end{array}$ & $\begin{array}{l}\text { different stratification period }\left(\mathrm{P}_{0} \text { to } \mathrm{P}_{4}\right) \text { and temperature }\left(\mathrm{T}_{1} \text { to } \mathrm{T}_{4}\right) \text { mentioned as, } \mathrm{P}_{0} \\
\text { (control, no stratification), } \mathrm{P}_{1}(2 \text { weeks }), \mathrm{P}_{2} \text { (4weeks), } \mathrm{P}_{3}\left(6 \text { weeks), } \mathrm{P}_{4}(8 \text { weeks) each under }\right. \\
\text { different temperatures of } \mathrm{T}_{1}\left(-4 \pm 1^{\circ} \mathrm{C} \text { in deep freezer), } \mathrm{T}_{2}\left(0 \pm 1^{\circ} \mathrm{C} \text { in freezer), } \mathrm{T}_{3}\left(4 \pm 1^{\circ} \mathrm{C}\right.\right.\right. \\
\text { in incubator), } \mathrm{T}_{4} \text { (room temperature). Regarding stratification period, } \mathrm{P}_{1}(2 \text { weeks }) \text { was } \\
\text { significantly best for its germination providing highest germination percentage }(70.50 \%) \text {, } \\
\text { germination capacity }(74.00 \%) \text {, germination energy }(30.08 \%) \text { and germination speed }\end{array}$ \\
\hline Article Info & \\
\hline $\begin{array}{l}\text { Accepted: } \\
15 \text { October } 2017 \\
\text { Available Online: } \\
10 \text { December } 2017\end{array}$ & $\begin{array}{l}\text { mination capacity }(67.87 \%) \text {, germination energy }(27.53 \%) \text { and germination speed } \\
\text { 73) germination value }(3.78) \text {, germination index }(1.70) \text {. From the present investigation, } \\
\text { vas concluded that stratification period of } 2 \text { weeks at room temperature }\left(\mathrm{P}_{1} \mathrm{~T}_{4}\right) \text { was best } \\
\text { seed germinability. Keeping in view the ecological and economic value of the species, }\end{array}$ \\
\hline
\end{tabular}

\section{Introduction}

Rhododendron arboreum Smith (Ericaceae), an evergreen tree is one of the 80 species of the genus Rhododendron in India with a widespread distribution in mountain ranges of India and Srilanka and is an important associate of sub-tropical pine forest found at an elevation from 1200-4000m above mean sea level attaining height of about $14 \mathrm{~m}$ having reddish-brown bark. The period of flowering / fruiting is March / April and June-September. In Himachal Pradesh, it is found in Chamba, Kangra, Kullu, Shimla, Mandi, Kinnour, and
Sirmour districts and is common in Shimla catchment, Gullu forest in Jogindernagar and Kalaghat in Solan (Chauhan, 1999). Rhododendron, one of the most important genus of Himalaya possessing various aesthetic, sacred, medicinal and commercial values with major use in landscaping, woodland planting and wood used in plough making and also a good fuel wood. Due to many biotic and abiotic disturbances and regular changes in environmental conditions, the natural regeneration of endemic species 
and their phenology is bound to be affected. For many of the rhododendrons overexploitation and its poor regeneration status in the form of available seedlings/saplings has caused a serious threat (Semwal and Purohit, 1980; Singh et al., 2008a; Singh et al., 2008b; Singh, 2009).

Moreover the process of germination is complex that is controlled by several biological (species, seed viability, seed dormancy, seed size) and environmental (moisture availability, temperature, relative humidity, light intensity and duration) factors and plant species vary in their response to these factors, it is important to determine the optimum conditions and seed treatments for germination and seedling establishment under the prevailing climatic conditions. Though studies have been conducted on different aspects of Rhododendron species (Singh et al., 2008a, 2008b; Singh, 2009), scanty information is available on seed germination parameters of this species. Many of the species are out of danger at present; however, these species are also in localized conditions and may be wiped out, if the proper measures are not taken (Tiwari and Chauhan, 2005). Keeping in view its germination and conservation status present study is undertaken to study the effect of stratification period and temperature on germination behaviour of Rhododendron arboreum Smith under laboratory conditions so as to formulate a germination protocol for this species.

\section{Materials and Methods}

The present study was conducted in the Department of Silviculture and Agroforestry, Nauni situated South-East of Solan town, at $30^{\circ} 51^{\prime} \mathrm{N}$ latitude and $76^{\circ} 11^{\prime} \mathrm{E}$ longitude having an altitude of $1250 \mathrm{~m}$ above mean sea level (msl) with sub-tropical to sub-temperate climate. The mature seeds (capsules) were collected from vigorous, middle aged and good form trees from sub temperate forest of (Shilli) Solan and surrounding area and brought to the department laboratory. These capsules were kept in shade in room temperature for 45 days until the seeds shattered from capsules prior to actual study. The seeds were made to germinate over filter paper for different stratification period $\left(\mathrm{P}_{0}\right.$ to $\left.\mathrm{P}_{4}\right)$ and stratification temperature $\left(\mathrm{T}_{1}\right.$ to $\left.\mathrm{T}_{4}\right)$ mentioned further.

Stratification of seeds was done for $\mathrm{P}_{0}$ (control, no stratification), $\mathrm{P}_{1}$ (2weeks), $\mathrm{P}_{2}$ (4weeks), $\mathrm{P}_{3}$ (6weeks), $\mathrm{P}_{4}$ (8 weeks) each under different temperatures of $\mathrm{T}_{1}\left(-4 \pm 1^{\circ} \mathrm{C}\right.$ in deep freezer), $\mathrm{T}_{2}\left(0 \pm 1^{\circ} \mathrm{C}\right.$ in freezer), $\mathrm{T}_{3}(4 \pm$ $1{ }^{\circ} \mathrm{C}$ in incubator), $\mathrm{T}_{4}$ (at room temperature). The data obtained was subjected to statistical analysis as per the methods detailed by (Steel and Torrie, 1960) and (Gomez and Gomez, 1984). The data were appropriately transformed wherever required before subjecting to ANOVA. The trial was kept under proper observation so that best treatment can be worked out. The experiment was laid out in Completely Randomized Design (factorial) with three replications to study following parameters.

\section{Germination per cent ( $\mathrm{g} \%$ )}

The per cent germination was calculated by number of seeds in a given sample that actually germinated.

$$
\begin{array}{r}
\text { Germination }(\%)=----------------- \text { X } 100 \\
\text { Total no. of seed kept for germination }
\end{array}
$$

\section{Germination capacity (gc \%)}

It is calculated as the cumulative number of seeds that germinated during the given days of test period plus the number of viable seeds at the end of the test expressed in percentage. 


\section{Germination energy (ge \%)}

Germination energy is a measure of speed of germination and hence is the indicator of the vigour of seed and of seedling.

Number of seeds germinated up to time of peak germination

Germination energy $(\%)=$ Total number of seeds sown

\section{Germination rate / speed}

Germination speed was worked out by the method prescribed by Maguire (1962).

Speed of germination $=\Sigma(\mathrm{n} / \mathrm{t})$

Where,

$\mathrm{n}=$ number of seeds newly germinated at time $\mathrm{t}$

$\mathrm{t}=$ number of days for sowing

\section{Mean daily germination (mdg)}

Mean daily germination was calculated as the cumulative germination percentage of seeds at the end of the test period divided by the number of days from sowing to the end of the test or the total days.

\section{Peak value (pv)}

Peak value (pv) was calculated as the maximum mean daily germination (mdg) reached at any time during the period of test (Czabator, 1962).

\section{Germination value (gv)}

Germination value is the index combining speed and completeness of seed germination. Daily germination counts were recorded and calculated as per Czabator (1962).

$\mathrm{Gv}=\mathrm{pv} \times \mathrm{mdg}$

$\mathrm{pv}=$ peak value of germination

mdg $=$ mean daily germination

\section{Germination index}

Germination index was calculated by dividing the total number of seed germinated at the end of the experiment by the time taken for fifty per cent germination.

\section{Results and Discussion}

The seed germinability of Rhododendron arboreum (Table 1) exhibited the declining trend as the stratification proceeds from 2 weeks $\left(\mathrm{P}_{1}\right)$ upto 8 weeks $\left(\mathrm{P}_{4}\right)$. The stratification upto 2 weeks $\left(\mathrm{P}_{1}\right)$ recorded maximum germination percentage $(70.50 \%)$, germination capacity $(74.00 \%)$, germination energy $(30.08 \%)$, germination speed (1.72), germination value (4.33), germination index (1.75). The germination beyond that limit resulted in a gradually dwindling ability of seeds to germinate upto 6 weeks $\left(\mathrm{P}_{3}\right)$ after which a rapid decline was observed in germination percent $(8.17 \%)$ upto 8 weeks. A similar trend was observed in germination capacity, germination energy, germination speed, germination value, germination index. Edwards (1982) reported that the germinability of temperate species rose as the stratification duration was doubled from the traditional time, but tripling the duration proved counterproductive, yielding less than optimum germination. This also been observed in Pinus elliotti (Barnett and McLemore, 1984); Cedrus deodara and Cedrus libani (Takos and Merou, 2001). The germinability of Rhododendron arboreum seeds (Table 2) was observed maximum at room temperature followed by $\mathrm{T}_{4}\left(4 \pm 1^{0} \mathrm{C}\right)$ temperature. The maximum germination per cent $(55.87 \%)$, germination capacity $(67.87 \%)$, germination energy (27.53\%), germination speed (1.73), germination value (3.78), germination index (1.70) was observed at room temperature and these germination attributes were followed by $\mathrm{T}_{3}\left(4 \pm 1^{0} \mathrm{C}\right)$ temperature providing germination per cent 
(48.27\%), germination capacity (64.40\%), germination energy $(22.27 \%)$, germination

speed (1.30), germination value (3.04), germination index (1.24).

Table.1 Effect of different stratification periods on seed germinability of Rhododendron arboreum $\mathrm{Sm}$

\begin{tabular}{|c|c|c|c|c|c|c|}
\hline $\begin{array}{l}\text { Period: } \\
\text { days }\end{array}$ & $\begin{array}{c}\text { Germinat } \\
\text { ion }(\%)\end{array}$ & $\begin{array}{c}\text { Germinat } \\
\text { ion } \\
\text { Capacity } \\
(\%)\end{array}$ & $\begin{array}{c}\text { Germinat } \\
\text { ion } \\
\text { Energy } \\
(\%)\end{array}$ & $\begin{array}{l}\text { Germinat } \\
\text { ion Speed }\end{array}$ & $\begin{array}{l}\text { Germinat } \\
\text { ion Value }\end{array}$ & $\begin{array}{l}\text { Germinati } \\
\text { on Index }\end{array}$ \\
\hline $\mathbf{P}_{0}:$ Control & $\begin{array}{c}57.58 \\
(49.36)\end{array}$ & $\begin{array}{c}71.67 \\
(57.84)\end{array}$ & $\begin{array}{c}25.67 \\
(30.42)\end{array}$ & 1.42 & 3.39 & 1.34 \\
\hline$P_{1: 2}$ wks & $\begin{array}{c}70.50 \\
(57.19)\end{array}$ & $\begin{array}{c}74.00 \\
(59.42)\end{array}$ & $\begin{array}{c}30.08 \\
(33.25)\end{array}$ & 1.72 & 4.33 & 1.75 \\
\hline $\mathbf{P}_{2: 4}$ wks & $\begin{array}{c}61.00 \\
(30.20)\end{array}$ & $\begin{array}{c}66.17 \\
(54.51)\end{array}$ & $\begin{array}{c}29.33 \\
(32.67)\end{array}$ & 1.54 & 3.53 & 1.48 \\
\hline $\mathbf{P}_{3:} 6 \mathrm{wks}$ & $\begin{array}{c}27.67 \\
(30.20)\end{array}$ & $\begin{array}{c}54.08 \\
(47.37)\end{array}$ & $\begin{array}{c}14.58 \\
(21.51)\end{array}$ & 0.90 & 1.85 & 0.88 \\
\hline$P_{4: 8} \mathbf{~ w k s}$ & $\begin{array}{c}8.17 \\
(13.73) \\
\end{array}$ & $\begin{array}{c}49.58 \\
(44.76) \\
\end{array}$ & $\begin{array}{c}6.50 \\
(11.96) \\
\end{array}$ & 0.42 & 0.32 & 0.36 \\
\hline C.D.0.05 & $\begin{array}{c}1.06 \\
(0.89)\end{array}$ & $\begin{array}{c}1.20 \\
(0.72)\end{array}$ & $\begin{array}{c}1.90 \\
(1.58)\end{array}$ & 0.16 & 0.30 & 0.14 \\
\hline
\end{tabular}

Table.2 Effect of different stratification temperature on seed germinability of Rhododendron arboreum $\mathrm{Sm}$

\begin{tabular}{|c|c|c|c|c|c|c|}
\hline $\begin{array}{l}\text { Temperatur } \\
\text { e }\left({ }^{\circ} \mathbf{C}\right)\end{array}$ & $\begin{array}{c}\text { Germinati } \\
\text { on }(\%)\end{array}$ & $\begin{array}{c}\text { Germinati } \\
\text { on } \\
\text { Capacity } \\
(\%)\end{array}$ & $\begin{array}{c}\text { Germinati } \\
\text { on Energy } \\
(\%)\end{array}$ & $\begin{array}{l}\text { Germinati } \\
\text { on Speed }\end{array}$ & $\begin{array}{l}\text { Germinati } \\
\text { on Value }\end{array}$ & $\begin{array}{c}\text { Germinati } \\
\text { on Index }\end{array}$ \\
\hline$T_{1}:-4 \pm 1^{\circ} \mathrm{C}$ & $\begin{array}{c}35.00 \\
(31.84)\end{array}$ & $\begin{array}{c}59.27 \\
(50.45)\end{array}$ & $\begin{array}{c}15.73 \\
(20.18)\end{array}$ & 0.83 & 1.81 & 0.78 \\
\hline$T_{2}: 0 \pm 1^{\circ} \mathrm{C}$ & $\begin{array}{c}40.80 \\
(38.08)\end{array}$ & $\begin{array}{c}60.87 \\
(51.41)\end{array}$ & $\begin{array}{c}19.40 \\
(25.00)\end{array}$ & 0.95 & 2.11 & 0.94 \\
\hline $\mathrm{T}_{3}: 4 \pm 1^{\circ} \mathrm{C}$ & $\begin{array}{c}48.27 \\
(43.30)\end{array}$ & $\begin{array}{c}64.40 \\
(53.56)\end{array}$ & $\begin{array}{c}22.27 \\
(27.20) \\
\end{array}$ & 1.30 & 3.04 & 1.24 \\
\hline $\begin{array}{l}T_{4}: \text { Room } \\
\text { temp. }\end{array}$ & $\begin{array}{c}55.87 \\
(48.34) \\
\end{array}$ & $\begin{array}{c}67.87 \\
(55.70) \\
\end{array}$ & $\begin{array}{c}27.53 \\
(31.47) \\
\end{array}$ & 1.73 & 3.78 & 1.70 \\
\hline C.D..$_{0.05}$ & $0.95(0.80)$ & $1.07(0.64)$ & $1.69(1.41)$ & 0.14 & 0.27 & 0.12 \\
\hline
\end{tabular}


Table.3 Interaction effect of stratification period and stratification temperature (PxT) on seed germinability of Rhododendron arboreum $\mathrm{Sm}$

\begin{tabular}{|c|c|c|c|c|c|c|}
\hline Treatments & $\begin{array}{l}\text { Germination } \\
\text { percent }(\%)\end{array}$ & $\begin{array}{l}\text { Germination } \\
\text { capacity }(\%)\end{array}$ & $\begin{array}{c}\text { Germination } \\
\text { energy }(\%)\end{array}$ & $\begin{array}{c}\text { Germination } \\
\text { speed }\end{array}$ & $\begin{array}{c}\text { Germination } \\
\text { Value }\end{array}$ & $\begin{array}{c}\text { Germination } \\
\text { index }\end{array}$ \\
\hline $\mathrm{P}_{0}-\mathrm{T}_{1}$ & $6.33(48.64)$ & $71.00(57.42)$ & $29.33(32.79)$ & 1.50 & 3.30 & 1.45 \\
\hline $\mathrm{P}_{0}-\mathrm{T}_{2}$ & $56.67(48.83)$ & $71.00(57.42)$ & $29.67(33.00)$ & 1.53 & 3.41 & 1.46 \\
\hline $\mathrm{P}_{0}-\mathrm{T}_{3}$ & 58.67 (49.99) & $72.00(58.05)$ & $30.67(33.61)$ & 1.56 & 3.42 & 1.51 \\
\hline $\mathrm{P}_{0}-\mathrm{T}_{4}$ & $58.67(49.99)$ & 72.67 (58.48) & $30.67(28.19)$ & 1.56 & 3.43 & 1.50 \\
\hline $\mathrm{P}_{1}-\mathrm{T}_{1}$ & $64.67(53.53)$ & $68.67(55.96)$ & $22.33(29.78)$ & 1.39 & 3.67 & 1.41 \\
\hline$P_{1}-T_{2}$ & $66.00(54.34)$ & $72.00(58.06)$ & $24.67(36.26)$ & 1.45 & 4.20 & 1.52 \\
\hline$P_{1}-T_{3}$ & $75.33(60.23)$ & $76.00(60.68)$ & $35.00(36.47)$ & 1.97 & 4.24 & 2.02 \\
\hline $\mathrm{P}_{1}-\mathrm{T}_{4}$ & $76.00(60.67)$ & 79.33 (62.97) & $35.33(28.66)$ & 2.07 & 5.18 & 2.04 \\
\hline $\mathrm{P}_{2}-\mathrm{T}_{1}$ & $49.33(44.62)$ & $60.00(50.77)$ & $23.00(30.21)$ & 1.17 & 2.01 & 0.92 \\
\hline $\mathrm{P}_{2}-\mathrm{T}_{2}$ & $56.00(48.45)$ & $61.33(51.55)$ & $25.33(30.44)$ & 1.09 & 2.56 & 1.04 \\
\hline $\mathrm{P}_{2}-\mathrm{T}_{3}$ & $68.67(55.96)$ & $70.00(56.79)$ & $25.67(32.36)$ & 1.54 & 4.61 & 1.45 \\
\hline $\mathrm{P}_{2}-\mathrm{T}_{4}$ & $70.00(56.79)$ & $73.33(58.92)$ & $28.67(11.28)$ & 1.89 & 4.94 & 1.96 \\
\hline $\mathrm{P}_{3}-\mathrm{T}_{1}$ & $4.67(12.42)$ & $48.33(44.05)$ & $4.00(11.28)$ & 0.10 & 0.06 & 0.09 \\
\hline $\mathrm{P}_{3}-\mathrm{T}_{2}$ & $21.33(27.50)$ & $51.33(45.77)$ & $14.00(21.86)$ & 0.60 & 0.36 & 0.59 \\
\hline $\mathrm{P}_{3}-\mathrm{T}_{3}$ & $30.00(33.21)$ & $53.33(46.91)$ & $14.67(22.50)$ & 1.16 & 2.82 & 0.98 \\
\hline $\mathrm{P}_{3}-\mathrm{T}_{4}$ & $54.67(47.68)$ & $63.33(52.74)$ & $25.67(30.41)$ & 1.73 & 4.17 & 1.85 \\
\hline $\mathrm{P}_{4}-\mathrm{T}_{1}$ & $0.00(0.00)$ & $48.33(44.05)$ & $0.00(0.00)$ & 0.00 & 0.00 & 0.00 \\
\hline $\mathrm{P}_{4}-\mathrm{T}_{2}$ & $4.00(11.28)$ & $48.67(44.24)$ & $3.33(10.15)$ & 0.08 & 0.02 & 0.08 \\
\hline $\mathrm{P}_{4}-\mathrm{T}_{3}$ & $8.67(17.10)$ & $50.67(45.38)$ & $5.33(13.17)$ & 0.37 & 0.09 & 0.22 \\
\hline $\mathrm{P}_{4}-\mathrm{T}_{4}$ & $20.00(26.55)$ & $50.67(45.38)$ & $17.33(24.51)$ & 1.38 & 1.18 & 1.34 \\
\hline C.D. ${ }_{0.05}$ & $2.12(1.78)$ & $2.40(1.45)$ & $3.80(3.17)$ & 0.31 & 0.42 & 0.27 \\
\hline
\end{tabular}

*Figures in parentheses are arc-sine transformed values

Fig.1 Seed stage

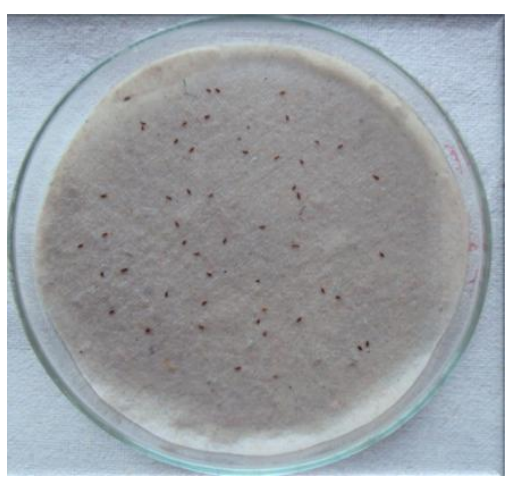

Fig.2 Germination stage

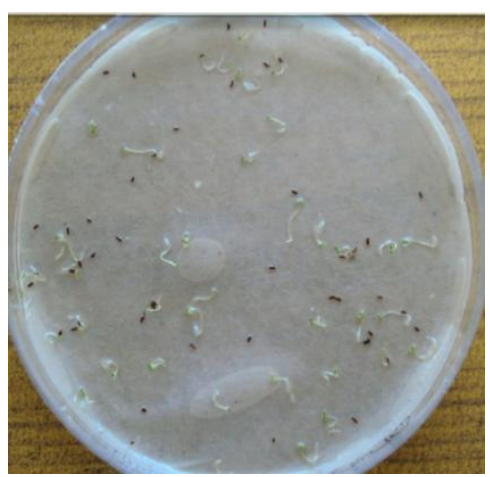

Fig.3 Seedling stage

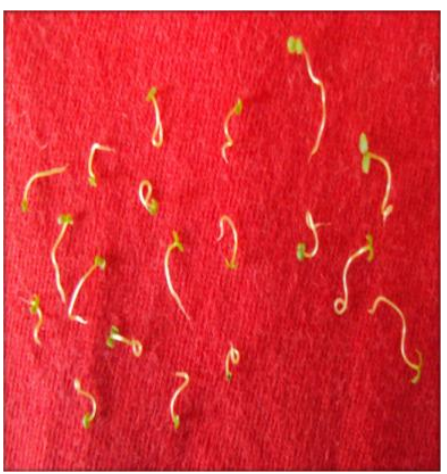

The interactions between stratification period and stratification temperature (Table 3) were significant for all the germination parameters.
It is evident from the data given in Table 3 that significantly maximum germination of $76.00 \%$ per cent resulted when seeds were 
stratified for 2 weeks at room temperature $\mathrm{P}_{1} \mathrm{~T}_{4}$. In this species the germination per cent, germination capacity, germination energy, germination speed, germination value, germination index were found to be maximum i.e. $76.00 \%, 79.33 \%, 35.33 \%, 2.07$, 5.18, 2.04 respectively in treatment $\mathrm{P}_{1} \mathrm{~T}_{4}(2$ weeks $\mathrm{x}$ room temperature). Popov (1986) observed that the germination was reduced by the longer period of stratification and also by low temperature. Dogra (2003) observed seeds of spruce stratified under wet conditions resulted highest germination percentage $(79.11 \%)$ and germination capacity (80\%) when seeds were stratified for 15 days at room temperature. From the present study, it can be stated that a significantly maximum germinability resulted when seeds were stratified for 2 weeks at room temperature $\left(\mathrm{P}_{1} \mathrm{~T}_{4}\right)$.

\section{Acknowledgement}

We thank the Deparment of Silviculture and Agroforestry of Dr YS Parmar University of Horticulture and Forestry, Nauni, Solan for providing necessary facilities.

\section{References}

Barnett, J. P., and McLemore, B. F. 1984. Germination speed as a predictor of nursery seedling performance. Southern Journal of Applied Forestry. 8: 157-162

Chauhan, N. S. 1999. Medicinal and aromatic plants of Himachal Pradesh, New Delhi. Indus Publishing Company. p. 632.

Czabator, F. I. 1962. Germination value: an index combining speed and completeness of pine seed germination. Forest Science. 8: 366-396.

Dogra, S. 2003. Effect of stratification and plant bio- regulator on the germination of fir and spruce. M.Sc. Thesis, Dr. Y. S. Parmar University of Horticulture and Forestry, Nauni-Solan, India.

Edwards, D. G. W. 1982. Improving seed germination in Abies species. Combined Proceedings - International Plant Propagators Society. 31: 69-78.

Gomez, K. A., and Gomez, A. A. 1984. Statistical Procedures for Agricultural Research (2nd ed.), J. Wiley and Sons Inc, New York, USA, p. 680.

Popov, P. P. 1986. Effect of stratification on the germination capacity of spruce seeds. Lesnoe Khozyaistvo. No. 11: 65-66 [Fty. Abs. 1987, 48(12) No.5316].

Semwal, J. K., and Purohit, A. N. 1980. Germination of Himlayan alpine and temperate potentilla. Proc. Indian Acad Sci. 89: 61-65.

Singh, K K., Kumar, S., and Pandey, A. 2008a. Soil treatments for improving seed germination of rare and endangered Sikkim Himalayan rhododendrons. World Journal of Agricultural Science. 4(2): 288-296.

Singh, K. K., Kumar, S., and Shanti, R. 2008b. Raising planting materials of Sikkim Himalayan Rhododendron through vegetative propagation using "Air-wet technique". Journal of American Rhododendron Society. 62: 136-138.

Singh, K. K., Rai, L. K., and Gurung, B. 2009. Conservation of Rhododendrons in Sikkim Himlaya: an overview. World Journal of agricultural Sciences. 5(3): 284-296.

Steel and Torrie, J. H. 1960. Principles and practices of statistics with special reference to the biological sciences. Mc Graw. Hill, London. p. 473.

Takos, I., and Merou, T. 2001. Effect of storage conditions and seed treatment on germination of Cedrus deodara LOUD and C. libani A.RICH. Silvae Genetica. 50(5-6): 205-208.

Tiwari, O. N., and Chauhan, U. K. 2005. Genus Rhododendron status in Sikkim Himalaya: an assessment. American-Rhododendron-SocietyJournal. 59(3): 147-158.

\section{How to cite this article:}

Vipasha, Sanyam, Navjot Singh Kaler and Varun Attri. 2017. Effect of Stratification Period and Temperature on Germination Behaviour of Rhododendron arboreum Smith. Int.J.Curr.Microbiol.App.Sci. 6(12): 1978-1983. doi: https://doi.org/10.20546/ijcmas.2017.612.227 